$10(1)(2021) 12-17$
Unnes Science Education Journal
Accredited Sinta 3

\title{
Science Process Skills in Science Education of Developed and Devel- oping Countries: Literature Review
}

\author{
Mercy Mushani ${ }^{\bowtie}$ \\ DOI: http://dx.doi.org/10.15294/usej.v10i1.42153 \\ Graduate School for International Development and Cooperation, Hiroshima University, Japan
}

\section{Article Info \\ Submitted 26 October 2020 Revised 21 November 2020 Accepted 17 February 2021}

\section{Keywords}

Science Process Skills, Science Education, Developed $\&$ Developing Country,

\begin{abstract}
The purpose of this literature review is to analyze and evaluate the research studies conducted on science process skills (SPS) in science education in the context of developed and developing countries. A follow-up to this study will investigate teacher facilitation of SPS development at Primary School level in Zambia. The method carried out in this study is a literature review. It involved analyzing and synthesizing some research work already conducted globally, considering the educational significance of SPS. The search was limited to peer-reviewed journal articles written in English and whose full papers were available on the databases. The articles were published between 1987 and 2018 because SPS's teaching and learning has been prevalent in research since the early 1980s. In total, 198 articles were found as a result of the initial search. The researcher screened abstracts of these articles to judge their relevance, and from this screening process of abstracts, 31 papers have been included for review. Reviewed study trends on SPS development conducted from developed and developing countries focusing on three vantage points: science curriculum, teacher education and the 21 st Century Learning. Based on the findings, more research studies on SPS in science education are carried out in developed countries than developing ones. The review findings indicate uneven inclusion of SPS in the science curriculum documents and the curriculum implementation at all science education levels. Lastly, results display few studies on SPS education regarding 21st Century Learning conducted in developed and developing countries. Concerned education bodies must take appropriate and reasonable exploits on teacher training of SPS education and the balanced inclusion of SPS in the science curriculum and its implementation into consideration. SPS still champions the development of other skills individuals are supposed to possess in this 21st-century era. Hence, SPS education in science education remains a need for both developed and developing countries.
\end{abstract}

\section{How to Cite}

Mushani, M. (2021). Science Process Skills in Science Education of Developed and Developing Countries: Literature Review. Unnes Science Education Journal, 10(1), 1217.

Correspondence Author:

E-mail: lusungu7@gmail.com 


\section{INTRODUCTION}

The building up of students' skills and allowing them to apply those skills in everyday lives in a scientific manner is the aim of science education Opulencia (2011). Activities or tasks that an individual does proficiently are a skill. When considered under science education, these skills incorporate SPS. SPS are exemplified as a set of all-embracing, interchangeable abilities, suitable to many science disciplines and reflective of a scientist's behaviour Padilla (1990). Regarding Padilla (1990), SPS are grouped into two, referred to as the Basic Science Process Skills (BSPS) and Integrated Science Process Skills (ISPS).

SPS belongs to one of the six domains of science: The Psychomotor Domain, particular as performance or practical skills Chabalengula et al. (2009). Therefore, SPS education needs everyone to understand the world around through empirical methods and scientific thinking. SPS are essential for student learning, and beneficial because they are cross-curricular, developed early in life. SPS are transferable thought processes; it is contended that both children and adults cannot use them appropriately Sunal \& Sunal (2003). SPS education needs teachers whose theoretical and practical awareness of these skills is high Chabalengula et al. (2012). Several sources of substantiations to elaborate on this concern are in previous research studies. To have a basis for investigating teachers' understanding of SPS, conducting this literature review is necessary. This would lead to more information on what has been reported from previous research work and a foundation to generate interventions for promoting quality of SPS education in science education.

The study's primary aim is to examine and evaluate SPS's research studies in different countries globally. The review process considered the research trends of SPS in science education from developed and developing countries. Outlined below are one (1) guiding question for the study: What are the research trends on science process skills focusing on three vantage points: science curriculum, teacher education and the 21st Century Learning?

\section{METHOD}

The relevant literature was accessed in October 2020 mainly through some search engines (Google Scholar, Scopus, ProQuest, Crossref) and followed by a manual search of the online database (Academia.edu, Science direct, Mende- ley and Eric) using search terms (" "Science Process Skills" and "Science Education" and "21St Century Learning")). In this study, science process skills were defined as a set of all-embracing, interchangeable abilities, suitable to many science disciplines and reflective of a scientist's behaviour Padilla (1990). Secondly, science education meant structured and unstructured teaching and science learning to non-scientists, such as school children in this study. Then 21st learning was defined as learning that enables students to master content while producing, synthesizing, and evaluating information from various subjects and sources to understand and respect a diverse culture. How do you define 21st-century learning (2010)? Therefore, these search terms were adequate to capture SPS education as the central theme of this review. The search was limited to peer-reviewed journal articles written in English and whose full papers were available on the databases. Additionally, the articles were published only between 1985 and 2018 because teaching and learning of SPS have been prevalent in research since the early 1980s. In line with the conceptual approach adopted in this paper, the other primary inclusion criterion was that the documents should have a component of SPS's educational significance.

In total, 198 articles were found as a result of the initial search. The researcher screened abstracts of these articles to judge their relevance in line with the above-described inclusion criteria. This screening led to 48 papers selected for further reading, while 150 were dropped because they focused on other skills such as Higher Order Thinking Skills (HOTS), Problem Solving Skills or their full papers could not be accessed. The 48 articles were further checked for duplication, i.e. articles appearing on both databases. From this screening process of abstracts, 31 papers have been included for review.

\section{RESULT AND DISCUSSION}

\section{Global Research Trends on SPS in Science Education}

This section provides literature review findings in research trends on SPS in science education globally while comparing developed and developing countries. The countries are into two: developed and developing, basing on the United Nations Development Programme's (UNDP) Country Classification System. The categorization criteria are from the Human Development Index (HDI) calculation, considering the multifaceted nature. The review findings are under three (3) categories of (1) Science Curriculum Perspec- 
tive, (2) Science Teacher Education Development Perspective and (3) The 21st Century Skills Development Perspective.

\section{Findings on Science Curriculum Perspective:}

The Organization for Economic Co-operation and Development through Programme for International Scientific Assessment (OECD-PISA) Project emphasizes that science curriculum should focus on both knowledge acquisition and offer means and ways for students' operational outcomes their science education Harlen (1999). There are three (3) main review findings in this section. One among the three is the inequality SPS inclusion in the science curriculum: research studies from both developed and developing countries have identified SPS's uneven inclusion in the science curriculum and assessment activities. And inappropriate analysis of science curriculum documents on SPS consideration as the main factor that negatively affects SPS education in the sciences teaching/learning process: Duruk et al., 2017; Downing \& Gifford, 1996; Siachibila \& Banda, 2018; Patonah et al., 2018. Secondly, one study findings from a developing nation point out that the variety of teaching approaches during the science learning process positively impacts SPS development Rauf et al. (2013). Thirdly the review findings on the trends in research under science curriculum perspective on SPS focuses more on the inclusion of SPS in science curriculum reference and assessment documents. The third finding is the science curriculum implementors' Behavioural influence. Attitude towards the science education of curriculum implementors such as teachers affects their performance on SPS education in the teaching and learning process Downing \& Filer (1999).

One of the most important goals of the science curriculum is to develop skills which lie under scientific thinking and decision referred to as SPS (Yumusak, 2016). The two categories of SPS; BSPS (Simpler) and ISPS (Complex) are interrelated. The BSPS are a basis for acquiring and developing the ISPS (Padilla,1990). Regularly the application of these skills is indissociable. SPS inclusion in science curriculum allows students to create and understand scientific ideas, life operations and skills alongside physical entity through studying the environment/living things. A profound goal of SPS inclusion in the curriculum is the emphasis on intellectual value rather than the importance of memorizing scientific facts or principles (Ostlund, 1992). Unfortunately, some previous studies review unbalanced inclusion and application of these skills in the science curriculum-an assertion that BSPS are more represented than ISPS ((Duruk et al., 2017). Table 1 below summarises the review findings in trend studies on SPS under science curriculum perspective.

Table 1. Results for Research Trends on SPS under curriculum perspective

\section{Similarities}

Study findings from developed and developing countries highlighted inadequacy in the inclusion of SPS in the curriculum.

Studies focused more on the inclusion of SPS in the science curriculum, reference, and assessment documents.

\section{Developed Countries Findings, Author, Country}

Insufficient display of ISPS in the science curriculum (Duruk et al., 2017) - Turkey

Teachers' performance in SPS can be affected by their attitude towards science (Downing \& Filer, 1999) - USA

Subjects whose SPS competency is at high level poses more critical questions and raises usage of diverse/ advanced items in teaching (Downing \& Filer, 1999) - USA

Less inclusion of some science process skills - classifying, predicting, communicating, constructing hypotheses in the textbook (Dokme, 2005) Turkey

Developing Countries Findings, Author, Country

In Indonesian textbooks, BSPS are prominent at upper elementary grades (G4 6). Whereas in Japanese textbooks, BSPS are eminent in lower elementary grades (G3) and ISPS are focused more at the upper elementary school level (Lumbantobing, 2005) - Indonesia

BSPS are more noticeable in the science curriculum for Junior school level (Patonah et al., 2018) -Indonesia

Teaching and learning science using several teaching methods during science classroom practice is beneficial regarding creating chances for teaching science process skills (Rauf et al., 2017) - Malaysia

Examining BSPS is given more preference compared to ISPS in Chemistry Practicals (Siachibila \& Banda, 2018) - Zambia

\section{Research Trends on SPS in Science Teacher Education Development Perspectives}

Under this category, the review findings indicate the inadequacy of conceptual understanding of 
SPS for both in-service and pre-service teachers Karsli et al. (2009), a disparity between pre-service teachers and in-service teachers' SPS understanding levels with the in-service teachers being better Kruea-In et al. (2015). Then, pre-service teachers' performance on SPS was reasonable compared to their theoretical knowledge (Chabalengula et al., 2012). The critical role that teacher educators play in helping prospective teachers develop SPS can never be overlooked Molefe et al. (2016). The significant influence of short-term science education programs and peer teaching strategies on SPS development are among some significant findings (Foulds \& Rowe,1996; Agoro \& Akinsola, 2013). A clear presentation of the review findings under this perspective is in Table 2 .

Table 2. Research Trends on SPS in Science Teacher Education Development for Developed and Developing countries

Developed Countries Findings, Author, Country Brief courses in science education may influence significant SPS development. Nevertheless, a need for further SPS development by considering more vital treatment programs for student teachers (Foulds \& Rowe, 1996) - Australia

Pre-service teachers' performance on SPS was better than their conceptual understanding of the same skills. Based on their inability to provide reasonable abstract definitions and explanations of the SPS (Chabalengula, Mumba \& Mbewe, 2012) - USA Majority of science teachers lack theoretic knowledge about SPS (Karsli, Şahin \& Ayas, 2009) - Turkey

Developing Countries Findings, Author, Country

Teacher educators play an essential role instructionally in pre-service education as their practice influences the development of students' SPS (Molefe, Stears \& Hobden, 2016) - South Africa

Preservice science teachers SPS in integrated science is enhanced using Reflective-Reciprocal Teaching and the Reflective- Reciprocal Peer Teaching strategies (Agoro \& Akinsola, 2013) Nigeria

In-service teachers' understanding of SPS is higher than that of the pre-service teachers. Despite this, both groups' score for inferring skill is low (KrueaIn, Kruea-In \& Fakcharoenphol, 2015) - Thailand

Trends in research under the teacher education perspective have emphasized intensive science teacher preparation on SPS development as critical in the provision of quality science learning in education. Teacher educators support pedagogical optimism, which benefits abstract understanding rather than SPS's acquiring within their practice (Molefe et al., 2016). SPS proficiency besides science content is a critical component of teaching science competency at any level of education.

\section{Research Trends on SPS in the 21st Century Learning Perspective}

SPS can make the student better talented to meet the life demands of the 21st Century Osman \& Vebrianto (2013). Acquisition and development of SPS enable students to solve problems, think critically, make decisions, find answers and satisfy their concerns Remziye et al. (2011). The significance of teaching students SPS is to enable them to describe objects, and events ask questions, construct explanations, test those explanations against current scientific knowledge and communicate their ideas to others Opara (2011). In table 3, a summary of findings from previous studies done in developed and developing countries regards this section is below.

Table 3. Summary of Trend Studies findings on SPS in the 21st Century Learning

\section{Developed Countries Findings, Author, Country \\ SPS have a significant role in science education (Demirbaş \& Tanriverdi, 2012) - Turkey \\ SPS learning by students can be promoted when using tools such as a microcomputer, using the file-management program and struc- tured activities (Berge, 1990) - USA}

\section{Developing Countries Findings, Author, Country}

The SPS emphasized in this study helped the experimental groups perform better in chemistry than the control groups (Abungu, Okere \& Wachanga, 2014) - Kenya

Students taught using the ICT and environment strategies obtained better results in the SPS and achievement test compared to students taught using the conventional technique (Osman \& Vebrianto, 2013) - Indonesia

The 21st-century skills can be cultivated through scientific literacy and SPS as in corresponding to advances in technology and the blast of information in the digital age (Turiman et al., 2012) - Malaysia

The review findings above reveal that SPS still champion the development of other science teaching and learning processes; thus, it must not be overlooked in this 21st-century learning era. 21st-century learning is the kind of education that enables students to master content while producing, synthesizing, and evaluating information from various subjects and 
sources with an understanding of and respect for diverse culture Kayange \& Msiska (2016). SPS is an essential key factor that influences one's education. When well acquired and developed by individuals, it can enable them to make positive contributions to economic developments in this 21st-century era and future life. SPS development through science learning still is a requirement even in this age of time. 21 stcentury learning is about interactions between theory and practice, individuals and communities, formal and informal learning, learners and meta-cognitive brokers Lee \& Hung (2012). In comparison to developed countries, a teacher might be the only resource available to facilitate SPS development through 21st Century learning in science for students in many parts of developing countries

Based on the findings, more research studies on SPS in science education are conducted in developed countries than developing ones. The review findings indicate uneven inclusion of SPS in the science curriculum documents and the curriculum implementation at all science education levels. Furthermore, results display few studies on SPS education regarding 21st Century Learning conducted in developed and developing countries. In addition to stating how high-level teachers' understanding of these skills leads to effective, efficient, and quality implementation of science education at any level, studies reviewed outlined the importance of introducing SPS education at the primary school level. Therefore, it is necessary to consider a balanced inclusion of SPS in the science curriculum at all levels of education and enhance quality pre-service and in-service teacher education training programs for raising SPS development and implementation, especially in developing countries.

\section{CONCLUSION}

In conclusion, SPS are of noteworthy in science education from way back until now. Several studies have outlined that SPS development in science education remains a need for developed and developing countries. This is because SPS still champions the development of other skills individuals are supposed to possess for their daily life use.

\section{REFERENCES}

Abungu, H. E., Okere, M. I. O., \& Wachanga, S. W. (2014). The Effect of Science Process Skills Teaching Approach on Secondary School Students' Achievement in Chemistry in Nyando District, Kenya. In Journal of Educational and
Social Research, 4(6), 359-372.

Agoro, A. A., \& Akinsola, M. K. (2013). Effectiveness of reflective-reciprocal teaching technique on pre-service teachers' achievement and science process skill in integrated science. International Journal of Education and Research, 1(8), 1-20.

Berge, Z. L. (1990). Effects of group size, gender, and ability grouping on learning science process skills using microcomputers. In Journal of Research in Science Teaching, 27(8), 747-759.

Chabalengula, V., Mumba, F., Hunter, W., \& Wilson, E. (2009). A model for assessing students' science process skills during science lab work. Problems of Education in the 21st Century, 11(2), $28-36$.

Chabalengula, V. M., Mumba, F., \& Mbewe, S. (2012). How pre-service teachers understand and perform science process skills. In Eurasia Journal of Mathematics, Science and Technology Education, 8(3), 167-176.

Demirbaș, M., \& Tanriverdi, G. (2012). The Level of Science Process Skills of Science Students in Turkey. In International Conference New Perspectives in Science Education, 1022-1027.

Dökme, I. (2005). Evaluation of 6th Grade Textbook Published by the Turkish Ministry of Education in Terms of Science Process Skills, 4 (1), 7-17

Downing, J. E., \& Filer, J. D. (1999). Science Process Skills and Attitude of Preservice Elementary Teachers. In Education, 11(2), 57-64.

Downing, J. E., \& Gifford, V. (1996). An investigation of pre-service teachers' science process skills and questioning strategies used during a demonstration science discovery lesson. In Journal of Elementary Science Education, 8(1),

Duruk, U., Akgün, A., Dogan, C., \& Gülsuyu, F. (2017). Examining the Learning Outcomes Included in the Turkish Science Curriculum in Terms of Science Process Skills: A Document Analysis with Standards-Based Assessment. In International Journal of Environmental and Science Education, 12(2), 117-142

Harlen, W., 1999. Purposes and procedures for assessing science process skills. Assessment in Education, 6(1): 129-140

Foulds, W., \& Rowe, J. (1996). The enhancement of science process skills in primary teacher education students. In Australian Journal of Teacher Education, 21(1).

Karsli, F. \& Sahin, C. (2009). Developing worksheet based on science process skills: Factors affecting solubility. In Asian-Pacific Forum on Science Learning and Teaching, 10 (1), 1.

Karsli, F., Şahin, Ç., \& Ayas, A. (2009). Determining science teachers' ideas about the science process skills: a case study. In Procedia - Social and Behavioral Sciences, 1(1), 890-895.

Kayange, J. J., \& Msiska, M. (2016). Teacher Education In China : Training Teachers For The 21st Century. In The Online Journal of New Horizons in Education, 6(4), 204-210. 
Kruea-In, C., Kruea-In, N., \& Fakcharoenphol, W. (2015). A Study of Thai In-Service and PreService Science Teachers' Understanding of Science Process Skills. Procedia - Social and Behavioral Sciences, 197(February), 993-997.

Lee, S.-S., \& Hung, D. (2012). Is There an Instructional Framework for 21st Century Learning? Creative Education, 03(04), 461-470.

Lumbantobing, R. (2005). A Comparative Study on Process Skills in Elementary Science Curriculum and Textbooks between Indonesia and Japan.

Molefe, L., Stears, M., \& Hobden, S. (2016). Exploring student teachers' views of science process skills in their initial teacher education programmes. In South African Journal of Education, 36(3), 1-12.

Mumba, F., Miles, E., \& Chabalengula, V. (2018). Elementary Education In-service Teachers' Familiarity, Interest, Conceptual Knowledge and Performance on Science Process Skills. In Journal of STEM Teacher Education, 53(2).

Opara, J.A. (2011). Some considerations in achieving effective teaching and learning in science education. In Journal of Educational and Social Research, 1 (4).

Opulencia, L.M. (2011). Correlates of Science Achievement Among Grade-VI Pupils In Selected Elementary Schools San Francisco District, Division of San Pablo City. Laguna State Polytechnic University

Osman, K., \& Vebrianto, R. (2013). Fostering science process skills and improving achievement through the use of multiple media. In Journal of Baltic Science Education, 12(2), 191-204.

Ostlund, K. L. (1992). Science Process Skills - Assessing Hands-On Students Performance: New York: Addison-Wesley
Padilla, J.M. (1990). The Science Process Skills (Research Matters to the science teacher No. 9004) Retrieved from National Association of Research in Science Teaching, website: http//www.narst.org/ publications/research skills.cfm

Patonah, S., Nuvitalia, D., \& Saptaningrum, E. (2018). Content analysis of science material in junior school-based inquiry and science process skills. In Journal of Physics: Conference Series, 983(1).

Remziye Ergul, Simsekli, Y., Calis, S., Ozdilek, Z., Gocmencelebi, S., \& Sanli, M. (2011). The Effects Of Inquiry-Based Science Teaching On Elementary School Students' Science Process Skills And Science Attitudes. In Bulgarian Journal of Science and Education Policy (BJSEP), 5(1), 48-69.

Rauf, R. A. A., Rasul, M. S., Mansor, A. N., Othman, Z., \& Lyndon, N. (2013). Inculcation of science process skills in a science classroom. In Asian Social Science, 9(8),47-57.

Siachibila, B., \& Banda, A. (2018). Science Process Skills Assessed in the Examinations Council of Zambia ( ECZ ) Senior Secondary School Chemistry-5070 / 3 Practical Examinations. In Chemistry and Materials Research, 10(5), 17-23.

Sunal, D.W., \& Sunal, C.S. (2003). Science in the elementary and middle school. Upper Saddle River. Pearson Education.

Turiman, P., Omar, J., Daud, A. M., \& Osman, K. (2012). Fostering the 21st Century Skills through Scientific Literacy and Science Process Skills. In Procedia - Social and Behavioral Sciences, 59, 110-116.

Yumusak, G. K. (2016). Science Process Skills in Science Curricula Applied in Turkey. In Journal of Education and Practice, 7(20), 94-98. 